\title{
Sanat Disiplinlerinde Bir İmge: Kapı Anahtarları
}

\author{
An image in art disciplines: the Latch keys
}

\section{Halil Fazll Ercan}

Dr. Öğr. Ü., İnönü Üniversitesi Güzel Sanatlar ve Tasarım Fakültesi Seramik Bölümü, fazil.ercan@inonu.edu.tr

\section{$\ddot{O ̈ z}$}

Eski çağlardan günümüze kadar yaşamımız içerisinde varlığını sürdüren anahtar, insanın hem kendisini hem de değerli gördüğü eşyalarını korumak ve saklamak için kullandığı önemli bir araç olmuştur. Anahtarlar; korumak ve saklamak eylemleri dişında kültürden kültüre farklılıklar gösterebilen kendine has formlarının yanı sıra bu formların üzerindeki dekoratif ve sembolik işlemeleriyle de değer taşımaktadır.

Anahtarlar sanatç1lar için de gerek arkaik gerek etnografik gerekse de günümüz çağdaş sanat anlayışı içerisinde işlevsel, biçimsel ve sembolik özellikleriyle önemli bir ilham nesnesi ve imge olmuşlardır.

Araştırmada anahtar formunun sanatta direkt ya da dolaylı bir imge olarak kullanımının tespit edilmesi amaçlanmıştır. Araştırmanın, plastik sanatlarda çalışmalar yapan sanatçılarda farkındalık duygusu oluşturacağı, anahtar formunun gerek biçimsel gerek işlevsel yönüyle günümüz sanatında da bir imgelem konusu olarak ele alınabileceği ve sanatta kullanılabilecek bir imge olması açısından önemli olabileceği düşünülmektedir.

Araştırmada Betimsel Yöntem kullanılmıştır. Alan yazında literatür taraması yapılarak, araştırma kapsamında icat edildiği dönemden beri yaşamımızın önemli bir araç-gereci olan anahtarın insanlık tarihindeki süreci ile biçimsel ve sembolik özellikleri araştırılmıştır. Ayrıca plastik sanatlarda kapı anahtarlarını doğrudan ya da dolaylı biçimde imgelem konusu olarak ele alan sanatçılar ve eserleri araştırılmış olup, yapılmış olan eserler biçimsel ve teknik açıdan incelenmiştir.

Araştırmanın sonucunda elde edilen bulgular 1şı̆̆ında, anahtar formunun biçimsel yapısı ve anlamsal değerleriyle sanatsal pratikleri ortaya koymada önemli bir nesne olarak işlendiği söylenebilir. Yaşam kültüründe yer alan işlevsel araç gereçler içinde anahtar formları, söz konusu araç gereçlerin işlevselliklerinin de ötesinde sanatta güçlü bir imge veya imgeleme dönüşebileceğine örnek teşkil ettiği düşünülmektedir.

Anahtar Kelimeler: Sanat, İmge, Seramik, Kapı Anahtarı

\section{Abstract}

The latch key that has existed in our lives from the old ages to the present has been an important tool that man has used to protect and store both himself and his belongings. Apart from their features to protect and hide, latch keys are worthy of their unique forms 
that can vary from culture to culture, as well as their decorative and symbolic embroidery on these forms.

The latch keys have become an important object of inspiration and image for artists with their functional, formal and symbolic features within both the understanding of archaic, ethnographic, and contemporary art.

The aim of the study is to determine the use of latch key form as a direct or indirect image in art. It is thought that the research will create a sense of awareness in the artists who work in plastic arts, beside this the latch key form can also be considered as an imagery subject in today's art with its both formal and functional aspects and it may be important in terms of being an image that can be used in art.

In this research, descriptive method has been used. Moreover, by making a literature review, the process of the latch key which has been an important tool of our lives in the history of mankind, and its formal and symbolic features have been researched since the time it was invented. Furthermore, the artists and their works which handle the latch keys as a subject of imagery directly or indirectly in plastic arts were investigated and the artifacts were examined in terms of form and technique.

In the light of the findings of the research, it can be said that the latch key form has been processed as an important object in revealing the formal structure and semantic values and artistic practices. Among the functional tools involved in our lives, the latch key forms can be considered as an example of the fact that these tools can be transformed into a powerful image or imagination in art beyond their functionality.

Keywords: Art, Image, Ceramic, Latch Key

\section{Giriş}

Anahtar kelimesi Türk Dil Kurumu sözlüğünde;

1. (isim) Kilidi açıp kapamak için kullanılan araç, açkı, miftah, dil. 2. Kurgu. 3. Şifre yazmak ve çözmek için kararlaştırılmış olan yol. 4. Somunları veya vidaları çevirerek sıkıştırıp gevşetmek için kullanılan çelik saplı araç. 5. Konserve kutularının kapağını keserek açmaya yarayan alet, açacak. 6. Vesile, araç, vasıta. 7. (sıfat) Herhangi bir olayda belirleyici olan. 8. (fizik) İstenilen yere veya aygıta, isteğe göre elektrik akımının geçmesini sağlamak için kullanılan düzen, çevirici, çevirgeç, şalter, komütatör. 9. (müzik) Notaların müzik merdivenindeki yükseklik derecelerini göstermek ve buna göre okunmasını sağlamak için portenin başına konulan işaret (Anahtar, t.y.) olarak açıklanmaktadır.

Anahtar kelimesinin çok zengin bir anlam çeşitliliğine sahip olduğunu görmekteyiz. Bugün kullandığımız anahtar kelimesi; Müzikte; sol anahtarı, inşaat sektöründe; İngiliz anahtarı, bilimsel yazılarda; anahtar kelimeler, aydınlatmada; elektrik anahtarı, cennetin anahtarı vb. gibi çok farklı alanlarda ve anlamlarda karşımıza çıkmaktadır. İlk icat edildiği dönemlerde kapılar için üretilmiş olsa dahi ulaştığımız şu son yüzyılda özellikle kentler ve metropoller dünyasında; ev, işyeri, araba, kasa, dolap, masa vb. birçok yerde anahtarın kullanım alanı artmış gibi görünse de diğer yandan artık yavaş yavaş anahtar fiziksel olarak ortadan kalkıyor. Artık dijital teknolojilerin gelişimiyle birlikte ev kapıları 
bile parmak izi ile ya da cep telefonundaki aplikasyon ile açılıp kapatılıyor. Yani anahtar günümüz dünyasında yavaş yavaş metaforik bir imgeye dönüşmeye başladı. $\mathrm{Bu}$ çalışmada özellikle geçmişten günümüze kapı anahtarları, kap1 anahtarlarının plastik sanatlarda bir ifade aracı, bir imge olarak kullanımı konunun sınırlılıklarını oluşturmakta olup anahtarın tarihçesi, biçimsel, sembolik özellikleri sanatta bir etkilenim nesnesi olarak çalışılan sanat pratikleri araştırılacak ve incelenecektir.

Arkaik dönemlerden günümüze kadar gelinen süreçte insanlar icatlar yapmış ve bu icatlarının birçoğunu günlük hayatlarında kullanmışlardır. İcat ettikleri araç gereçleri işlevselliğinin ötesinde çeşitli anlamsal yüklemelerde yaparak sembolleştirmişlerdir. $\mathrm{Bu}$ araç gereçler gerek biçimsel gerekse üzerlerindeki motiflerle üretildiği toplumların kültürel izleriyle bezenmiştir. Tıpkı bir çocuğun aile ve çevresinden aldığı kültürel donanımla şekillenmesi gibi bu tür nesnelerde şekillendirildiği, üretildiği toplumların sosyolojik ve kültürel genlerini taşımaktadırlar. Anahtarlar da form ve sembolik duruşlarıyla bu kapsamda ele alınabilecek güçlü yaşam kültürü nesneleri arasındadır. Anahtar formları hem isimsel, işlevsel özelliği hem de dekore edilmiş estetik yapılarıyla toplumda önemli bir değere sahiptir. Geldiğimiz süreçte sanayi kültürü içerisinde endüstriyel bir ürün haline gelen, biçimsel ve dekoratif olarak minimalize olup yapısal görüntü olarak standartlaşan anahtarlar arkaik, etnografik döneme ait ihtişamlı duruşlarını yitirmiş dahi olsalar insan yaşamında işlevsel değeri ve sembolik değerleri azalmamış aksine artmıştır.

Anahtarın genel işlevi kilidi, köçeği açmak veya kapatmak kilitlemek dahi olsa işlevselliğinin ismine ve biçimine yüklediği özellikleriyle her an sanatçı içinde bir imgelem, etkilenim nesnesi olabilme ve toplumdaki genel algısının da ötesinde bir ifade aracına, sanat imgesine dönüşebilir. Bu bağlamda Arnheim şu tespiti yapmaktadır:

G. Braque'nin bir sözüne kulak vererek bir fincan yanında bulunan çay kaşı̆̆ııı ayakkabı ile topuk arasına yerleştirdiğimizde kaşığın bir anlamda ayakkabı çekeceğine dönüştügünü söylemesi, bir şeyin farklı anlamlar içerebileceğine işaret eder. Ayrıca sözcükler ve imgeler arasında görece rastlantısal ilişkiler kurulabilir ve düşüncelerin gördüklerimizle şekillenmesi sığ ve yoz düşünceye bir yorum kapıs1 açar (aktaran Albayrak, 2015, s. 12).

$\mathrm{Bu}$ durumu nesnelerin farklı bakış açılarıyla irdelendiğinde veya düşlendiğinde var olan işlevlerinin ve anlamlarının dışına çıkabileceğinin en güzel örneklemi olarak görebiliriz.

\section{Yöntem}

Araştırmada Betimsel Yöntem kullanılmıştır. Araştırmada literatür taraması yapılarak, yazılı kaynaklardan, internet kaynaklarından anahtarın tarihçesi, resim, heykel, seramik, grafik alanlarında anahtar formunu eserlerinde direkt ya da dolaylı imge olarak kullanan sanatçılar ve eserleri araştırılmıştır. Elde edilen bulgular doğrultusunda anahtar formunun imge olarak kullanıldığı eserler sanatsal açıdan irdelenmiştir.

\section{Anahtarın Tarihçesi}

Anahtar ve kilit arkaik dönemlerde icadından günümüze kadar gelinen zaman sürecinde insanın yanından ayırmadığı önemli bir eşyası olmuştur. İlk kapı kilitleri ve anahtarı ahşaptan yapılmıştır. Tarım ve hayvancılı̆̆ın başlaması yerleşik hayat tarzını da beraberinde getirdi. Yerleşik hayatla birlikte insanlar barınma ihtiyaçlarını gidermek için evler yapmaya başladılar. Yerleşik hayata paralel olarak çevredeki nüfusta artmaya 
başlayınca insanlar güvenlik ihtiyaçlarını gidermek için evlerinin ahşap kapılarına basit korunma kilitleri geliştirmeye başladı ve günümüze kadar gelen yaklaşık 7 bin yıl boyunca da bu korunma aracı gelişerek devam etmektedir. Anahtarın tarihsel geçmişi yapılan arkeolojik araştırmalarla elde edilen veriler 1şı̆̆ın da Tarih Öncesi Devirler (Prehistorik Devirler)'de denilen süreç içerisinde yer alan Kalkolitik (Taş-Bakır) (MÖ.5500-MÖ.2500) dönemine kadar uzanmaktadır. Saraçoğlu ve Karakaş; "Genel olarak, çağlar boyu kullandığımız tüm kilitlerin ana kaynağı 4000 yıl öncesindeki Mısır kilitlerine dayanır" demektedirler (Saraçoğlu ve Karakaş, 2007-2008, s. 148). Bu ahşap kilit ve anahtarların benzerlerinin Asurlular ve Badilliler tarafından da kullanıldığ belirlenmiştir. İlk ahşap kilit arkeologlar tarafından Pers'te, MÖ 722 ile 705 yılları arasında hüküm süren Asur Kral'1 Sargon II'nin Ninova yakınlarındaki Horsabad Sarayı'nın güvenlik kapısında bulunduğu belirtilmektedir (Schlage's History of Locks, t.y.) (Görsel 1).

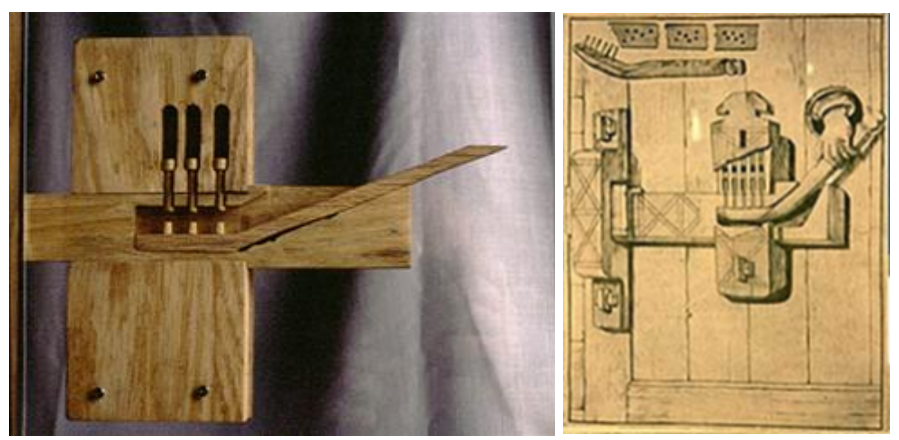

Görsel 1. Asur kilidi ve çizimi

Ahşap kapı kilitleri ve anahtarlarının Anadolu'daki varlığıyla ilgili olarak elde edilen arkeolojik veriler 1şı̆̆ında Frangipane (2004, s. 84) ve Şahin (2018); M.Ö.3500-3000'li y1llara tarihlenen Malatya Arslantepe Höyük Saray kalıntılarında ahşap kilitlerin ve anahtarlarının varlığından söz etmektedirler. Saray içerisinde bulunan ürün depolarında bu ahşap kilit ve anahtar sisteminin kullanıldığını belirtmektedirler.

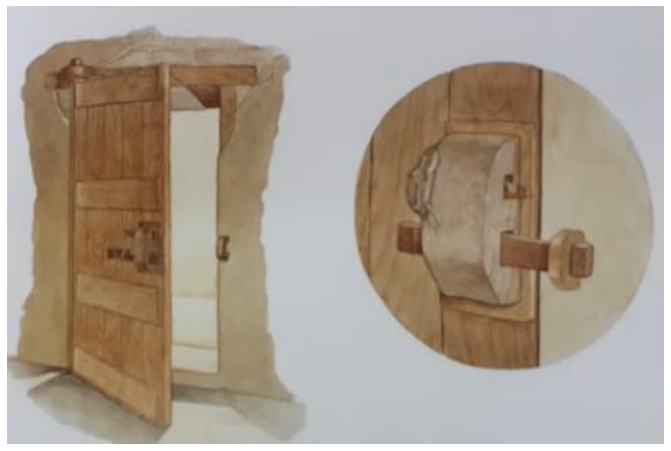

\section{Görsel 2. Ahşap Kilit Sistemi rekonstriksiyon çizim/Arslantepe Höyük}

Bu ahşap kilit ve anahtar sistemi ülkemizde 1980'li yıllara kadar Bursa, Antalya, Elazı̆̆ gibi illerde marangozlar tarafindan yapılıp çoğunlukla bahçe kapılarında kullanımı devam etmiştir. Malatya Arkeoloji Müzesi araştırmacılarından Hüseyin Şahin; Batı Karadeniz, Antalya, Elazı̆̆ yöresinde de rastlanan uygulamanın Malatya'da en çok Çırmıhtı (eski Yeşilyurt ilçe merkezi) ile yakınındaki Kileyik, Barguzu, Gündüzbey ile Arapgir ve Eski Malatya'da (eski Battalgazi ilçe merkezi) kullanıldığını belirtmektedir (Görsel 3). Şahin; Basit, akıllı bir mekanizmaya sahip, pağa teknesi (yatak)-sürgü/kol (zoğna), dil, anahtar 
ve kapak tahtasından oluşan kilitlerin özellikle bahçe kapılarında kullanıldığını ifade etmektedir (Şahin, 2018).

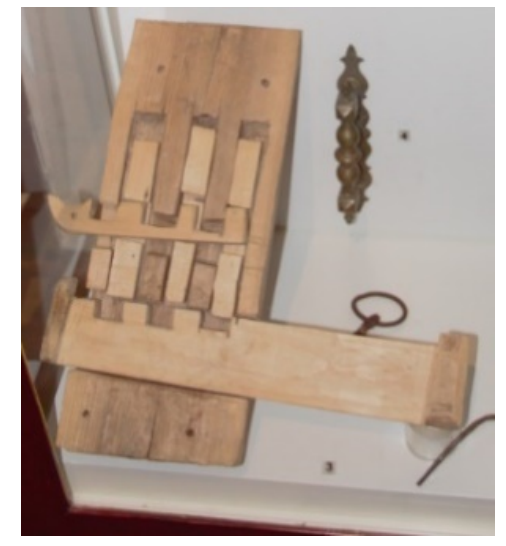

Görsel 3. Ahşap kilit ve anahtar/Malatya Etnografya Müzesi

Topkapı Saray Müzesinde sergilenen ahşap anahtarlar tarihsel itibariyle bu ahşap kilit sisteminin Osmanlı döneminde de Anadolu'da mevcudiyetinin birer örnekleridir (Ünal, 1963, s. 128).
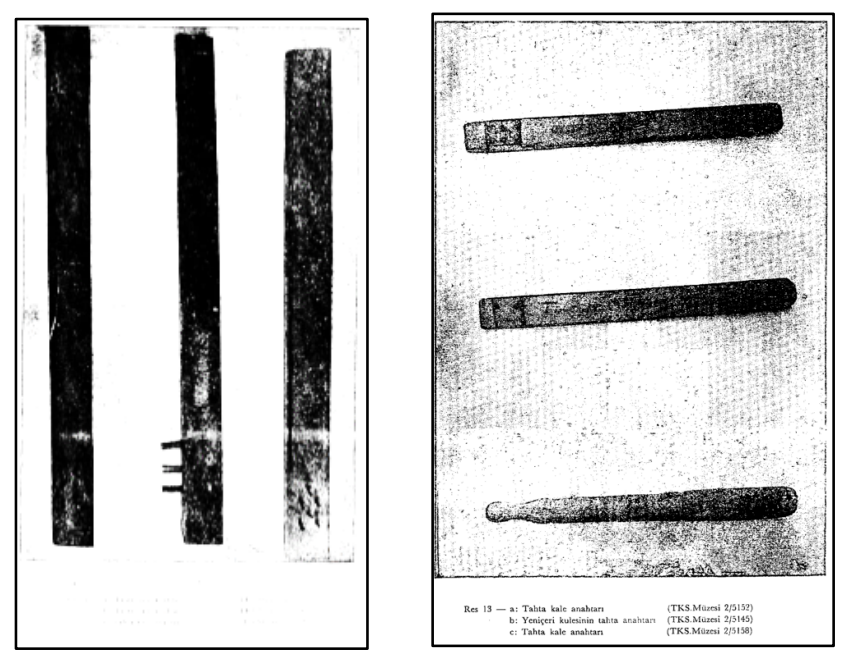

Görsel 4. Osmanlı dönemi ahşap kale anahtarları

Romalılar zamanında kilitler kayda değer bir değişim geçirdiler. Bu dönemde metalden yapılan kilitleri açabilmek için anahtarlar önem kazandı. Daha önceleri sarayların, şatoların bekçileri kapılardaki kocaman kilitleri kapayabilmek için 20$30 \mathrm{~cm}$ uzunluğunda, bir kiloya yakın ağırlıkta tunç anahtarlar taşımak zorunda kalırlardı. Derken asma kilitler boy gösterdi. Bu kilitleri ilk kez, Avrupa ve Asya arasında gidip gelen tüccarların kullandıkları biliniyor. Ortaçağda metal işlemeciliğin gelişmesiyle birlikte anahtarlar ve kilitler de adeta birer sanat eserine dönüşmeye başladı. Ustalar, anahtar ve kilitleri fildişi, pirinç gibi değerli malzemelerle süslüyorlardı (İşçen, 2008).

Konuyla ilgili olarak Saraçoğlu Çelik yaptığı araştırmalar 1şığında; "Eski Mısır, Çin, İran, Roma, Türk-İslam Kilitleri. Eski kilitler, günümüz kilitlerinin çoğunun kullandığı tambur ilkesine dayanıyordu. Romalıların kıyafetlerinin cepleri olmadığı için pek çok erken dönem Roma Anahtarı yüzük olarak takılıyordu" diye belirtmektedir (Saraçoğlu Çelik, 2015, s. 96). 


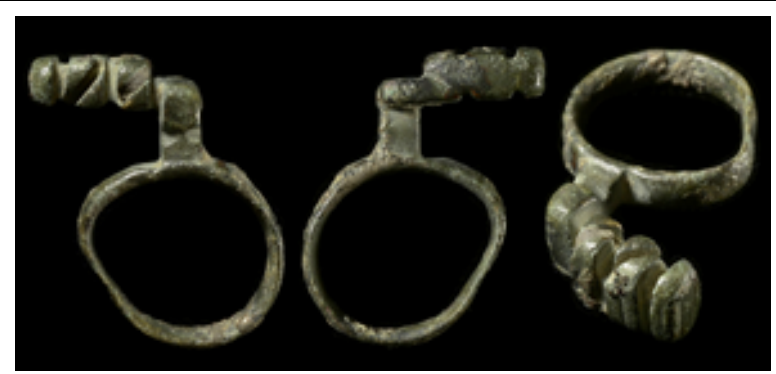

Görsel 5. Antik Roma bronz yüzük anahtar

İlk metal kilitler M.S. 800'lerin sonunda İngiltere'de ortaya çıtı. Sanayi Devrimi sırasında üretimde standartlaşma gelişince kilitler güvenilir hale geldi. Basit bir anahtarla sürgüyü ileri iterek kilitlenen sürgülü kilit, İngiltere'de 1778'de mükemmelleştirildi. İngiltere'de bir limanın deposundaki kilidi açan hırsızlar depoyu soymuştu. İngiliz hükümeti bu nedenle, maymuncukla açılamayacak bir kilit için para ödülü koydu. J. Chubb, 1818'de Chubb Tuzaklı Kilidini icat etti. Günümüzde kullanılan ve "Yale Kilit" olarak anılan döner silindirli kilidi, 1848'de ABD'de L. Yale icat etti (Akbulut, 2014, s. 2).

Topkap1 Müzesi asistanlarından İsmail Ünal Topkap1 Sarayı Müzesinde sergilenen Osmanlı dönemine ait kapı anahtarlarının mevcudiyetinden bahsetmektedir. Bu kilitlerin çoğunlukla kale kilitleri olduğunu, gümüş ve demir den üretilmiş olduklarını aktarmaktadır (Ünal, 1963, s. 119).
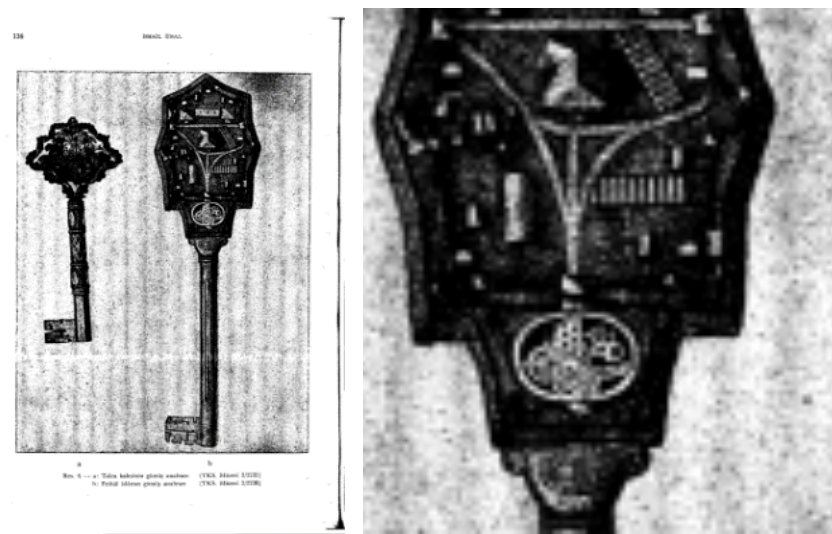

Görsel 6. Osmanlı dönemi gümüş anahtarları

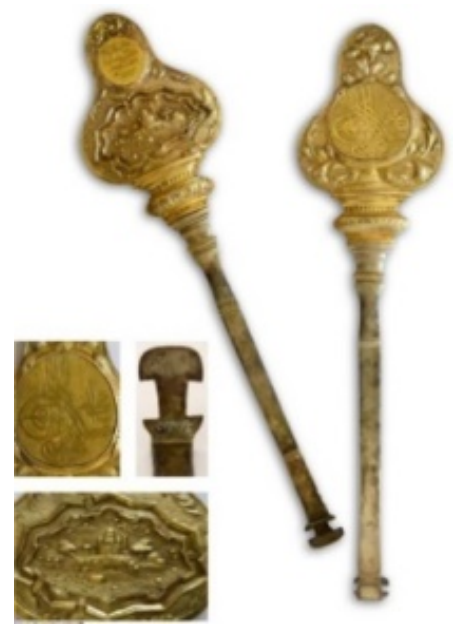

Görsel 7. Silistre Kalesi'nin gümüş anahtart 
Tarihi arkaik dönemlere kadar uzanan anahtarlar birer kültür taşıyıcıları ve sembol gibidirler. Yapıldıkları toplumun kültürel izlerini taşırlar. Kullanan kişilerin sembolleri olmuşlardır. Dinsel inançlarda da işlevselliklerinin getirdiği özelliklerinden kaynaklı sembol niteliği taşımıştır. Hıristiyanlığın kutsal kitabında; Matta 16: 18-19'da iddia edildiği gibi, Cennetin İnci Kapılarının büyük anahtarı ile: "Size Cennetin Krallığı'na anahtarlar vereceğim. Yeryüzüne bağladığınız şey cennete bağlı olacak ve yeryüzünde yerinden ettiğin şey cennete gömülecek" diye ifade edildiği belirtilmektedir (Allef, 2013). Müslümanlık inancında anahtar motifinin kullanımıyla ilgili olarak ta Zariç'in aktarımında; Anahtar Motifli: "Bismillahirrahmanirrahim miftahi kullu kitabin/Besmele her kitabın anahtarıdır." hadisi, Hâkim el Nişâburî'nin El-Mustedrak alâ el-Sahîheyn adlı hadis külliyatında yer almaktadır. Besmele motiflerinde sıklıkla rastlanan motiflerden biri de gerek bu hadisten gerekse anahtar nesnesinin özgürlüğü, başlangıcı simgelemesinden ötürü "anahtar" olmuştur diye belirtilmektedir (Zariç, 2017, s. 198).

Keşfedildiği arkaik dönemlerden günümüze kadar geçen süreç içerisinde boyut, biçim farklılıklarına uğrasa da her daim insanın yanından ayırmadığı bir parçası haline gelen anahtar işlevsel yönüyle, biçimsel yapısıyla bireyler ve topluluklar için yaşam süreci içerisinde önemli bir eşya niteliğindedir. Genel işlevi açmak, kilitlemek, saklamak, korumak, olan anahtarın işlevselliğinin yanı sıra boyutu ve üzerindeki ihtişamlı süslemelerinin de getirdiği güçlü anlamsal özelliğiyle; gücün sembolü, ihtişamın göstergesi, toplum içerisinde statü göstergesi, varlık göstergesi olarak ta toplumlarda karşı1lik bulmuştur.

Anahtarlar bireylerin ve toplumların kültürel elçileri gibidirler. Kuşaktan kuşağa ve toplumdan topluma yapıldıkları dönemlerin dolaylı olarakta olsa izlerini aktarırlar. Özellikle demir olarak yapılmaya başlandıktan sonraki süreçlerde üretilen anahtarların genel formlarının ve bu form yüzeylerinin çok farklı farklı şekillerle dekore edildiğini görmekteyiz. Günümüzde Anadolu'da, Avrupa'da, Afrika'da birçok ülkede müzelerde, özel koleksiyonlarda sergilenen ve arkeolojik, etnografik olarak nitelendirilen metal kap1 kilitlerinin dönemlerinin güçlü sanatkârları tarafında özenle yapıldı̆̆ı görülmektedir. Anahtarlar bu özellikleriyle de aslında yapıldıkları dönemlerde ve yerlerde işinin ehli sanatkâr demir ustalarının varlığının da birer ispatı olma özelliğini taşımaktadırlar. Anadolu'da Rumlar ya da Ermeniler tarafindan yapılan kilit ve anahtarlarda haç işareti bulunur. Osmanlı kilitlerini süslemelerindeki lalelerden ya da pirinç armadan tanırız. Ayrıca kilit veya anahtarın ev sahibinin sosyal statüsünü belirten bir işlevi de olduğu biliniyor. Kilidin büyüklüğü ve gösterişi, anahtarının süslemesi evin sahibinin zenginliğiyle doğru orantılıydı. Araştırmacı İşşen'in konuyla ilgili olarak yaptığ araştırmada; Kapadokya'da Türk, Rum ve Ermeni ustaların kilit işinde uzmanlaştıkları biliniyor... Her kilidin de şifre sistemi birbirinden farklıydı. Nevşehir'de eski kapı kilit ve anahtarlarına 'firek' denirdi. Kilit anahtarının uç kısmı sivri ise 'erkek firek', uç kısmı delik ise 'dişi firek' ismini alıyordu diye belirtilmektedir (İşçen, 2008). Nevşehir' in Uçhisar ilçesinde 43 yıldır kilit ve anahtar yapımıyla uğraşan Mehmet Yuğuran'da anahtarlarla ilgili olarak; "Selçuklu'da hayvan siluetli kilitler mevcut. Osmanlı'da bazı kilitlerin üzerinde pirinçten ya da demirden ayna dediğimiz kilidin gösterişini sağlayan semboller var. Bu sembollerde de kiminde kuş motifi kiminde güneş, kiminde ay-yıldız motifi görülmektedir. Eğer Hristiyan ya da Ermeni biri tarafından yapıldıysa, anahtar veya kilit üzerinde bir haç şekli görürsünüz. Bazen de sade bir düz ayna kullanılıyor. Zengin kişiler bu ayna dediğimiz yerleri pirinçten döküm yaptırıp, üzerine de sevdiği objeleri ekletiyor. Mesela güneş sembolü, o evin uzun süre hayatta kalmasını sembolize 
ediyor" diye belirtmektedir (Fikriyat, 2017). Anahtar üretiminin İstanbul'daki son sanatkârlarından Güngör Yanık'la ilgili olarak oğlu Sezgin Yanık; babasının yıllarını kilit ve anahtar üretimine adamış olduğunu babasının aslında bir bakır ustası olduğunu ve anahtarlara olan hevesinden dolayı anahtar üretmeye başlamış olduğunu belirtmektedir. Güngör ustanın yüreğindeki estetik hazzın ve hevesin 1şığıyla uzun yıllar kendine özgü bir tarzda anahtar tasarımları ve üretimi yaptığını belirtilmektedir (İşçen, 2015).

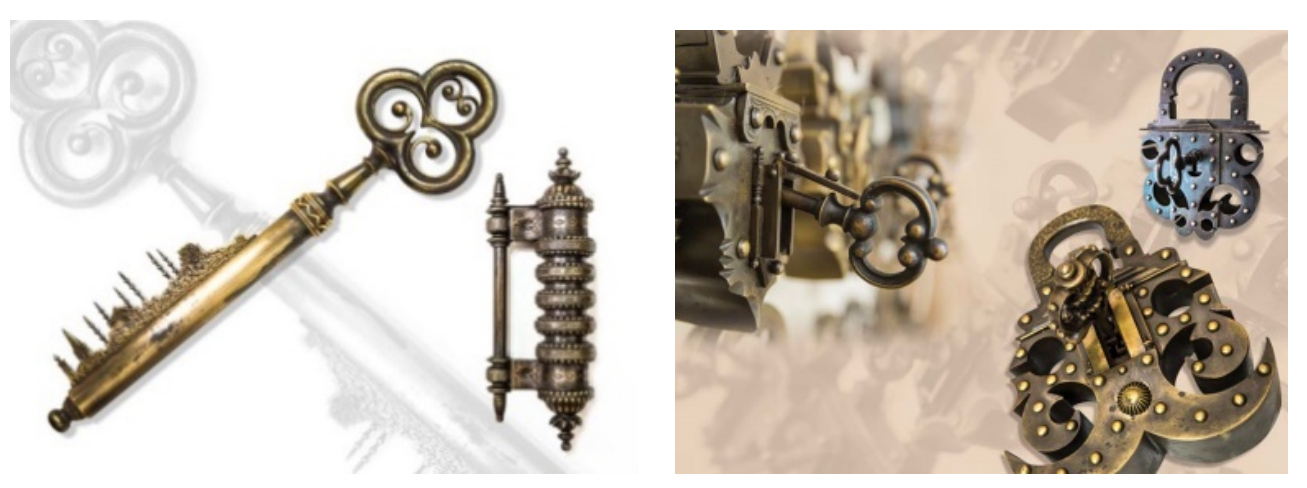

Görsel 8.Güngör Yanık, Kapı kilitleri ve anahtarları

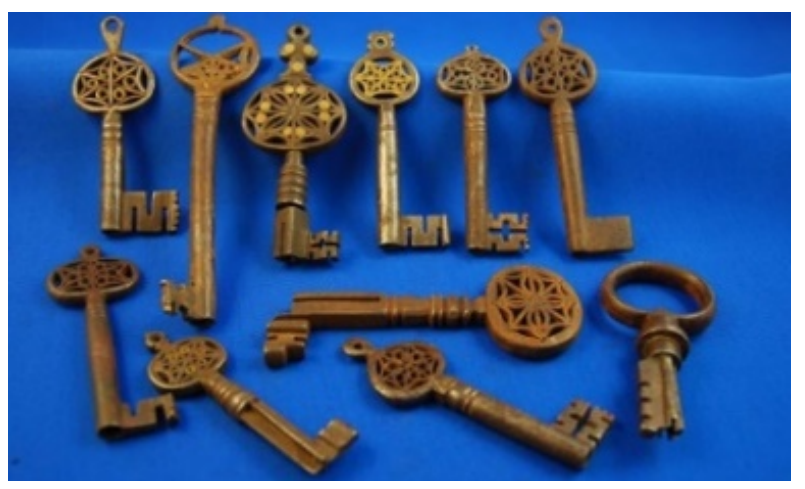

Görsel 9. Kapı anahtarlarl, Mehmet Yuğuran koleksiyonu

Dünyada ve ülkemizde hızla gelişen teknolojik ilerlemelere paralel olarak kilit ve anahtar üretimi de aşırı ihtiyaçtan kaynaklı olarak günümüzde endüstriyel bir ürün haline dönüşmüş̧ür. $\mathrm{Bu}$ dönüşümle birlikte anahtarlar geçmişteki boyut ve üzerlerindeki sanatsal özelliklerini yitirmiş olsalar da yine de yaşadığımız 21 yüzyılda insanların anahtara yükledikleri geçmişten süregelen anlamsal değerlerin birçoğu yeni eklentilerle birlikte devam etmektedir.

\section{Sanatta Anahtar İmgesi ve Örnekleri}

Bir gözlemci ve araştırmacı olan sanatçı için her an her şey bir etkilenim aracı olabilir, bu bazen somut bir nesne bazen soyut bir kavram olarak sanatçıda ussal, duygusal etkilenim uyandırabilir. Biçimi ve sembolik değerleriyle kapı anahtarları da gerek formu gerekse üzerine yüklenen anlamsal yönleriyle sanatçı için önemli bir imgeye dönüşebilir. Çok çeşitli formlara sahip bu anahtarlar bazen yorumlamacı bir üslupta bazen realist bir üslupta veya hazır nesne olarak sanatçının eserinde varlık gösterebilmektedir ve imge niteliği taşımaktadır.

İmge, Türkçe sözlükte; "1. Zihinde tasarlanan ve gerçekleşmesi özlenen şey, düş, hayal, hülya; 2. Genel görünüş, izlenim, imaj; 3. (psikoloji) Duyu organlarının dıştan algıladığı bir nesnenin bilince yansıyan benzeri, hayal, imaj; 4. (psikoloji) Duyularla algılanan, bir uyaran söz konusu olmaksızın bilinçte beliren nesne ve olaylar, hayal, imaj” olarak 
tanımlanmaktadır (İmge, t.y.). İmge bir benzerini yaratmak, aslından kalan izleri yansıtmaktır. Dış ya da iç gerçekliğin işaretçisi olan imge, aslının işaretçisidir. İmgeler bilincin ürünüdürler. Bilincin kültür, tarih ve toplumla şekillenmesi nedeniyle imgeler belli sosyo-kültürel ortamı gösterirler (Bayav, 2009, s. 107-108). Faruk Atalayer imge ve imgelemle ilgili olarak;

...her insan, toplumuna, çağına, sınıfına, kültürüne göre imge, imgelerine, imlem işlemlerini edinmekte, neredeyse doğal güdüler kadar kendiliğindenmiş gibi yapabilmektedir. Hiçbir sanatsal-tasarımsal, estetik eğitim almasa da, yaşadığ ortamdan, çevreden "toplumsal ortalama" olarak yansiyan, imge, imgelerine, imlem biçimlerini, anlamlarını, içeriklerini, alanlarını, üretme yöntemlerini edinir. Ya da edindirilir, hatta ezberlettirilir. İnsanlar, koşullanma, güdülenme sınırları kadar zihinsel kurgu yapabilirler demektedir (Atalayer, 2005, s. 1).

İmge ilk kez ortaya çıktığı yerden ve zamandan birkaç dakika ya da birkaç yüzyıl için kopmuş ve saklanmış bir görünüm ya da görünümler düzenidir. İmgeler başlangıçta orada bulunmayan şeyleri gözde canlandırmak amacıyla yapılmıştır (Berger, 1995, s. 10). İmgelem, edinilmiş imgeleri birleştirip kaynaştırma ve bu birleşiklerden yeni imgeler tasarlama yetisidir... Bir imgeyi yeniden canlandırmaktan yaratıcılığa kadar yükselir" demektedir (Hançerlioğlu, 2008, s. 184). İmgelemde yeniden canlandırma söz konusudur: Bellekte bulunan imgelerin çeşitli düzenlemelerle kurulması. İmgelem yaratıcılık ile birleşirse ancak o zaman nitelikli ürünler ortaya çıkabilir. İmgelem yalnız imgelerle düzenleme kurmak değildir; aynı zamanda sembol-imgeleri anlamak, bağlantıları görebilmek ve yeni bağlantılar kurgulayabilmektir. "İmgelemin, sanat etkinliği sürecinde ortaya koyduğu üç ayırıcı özelliği üzerinde durulmalıdır. Bunlar düşlem, yansıtma ve özdeşlemedir" (San, 2003, s. 61). Düşlem, zihinde oluşan gerçek dişı imgelemken, yansıtma imge ve sembol imgelerin plastiğe dökülmesidir. Özdeşleme ise kişinin imgenin bir parçası olmasıdır. Yeni tasarımlar ancak imgelem gücü sayesinde gerçekleşir. Yaratıcı düşünme ve kurgulamada bilinç öncesi düşünce etkindir. Ön yaşant1, gözlem ve eleştirel değerlendirmeden oluşan bilinç öncesi düşünceyi “...geçmiş yaşantıların ve bunların imgelerinin depolandığı yer olarak tanımlamak mümkündür” demektedir (San, 2003, s. 58). Ortaçağ sanatının amacı kutsal öğretileri insanlara resimler yoluyla iletmekti. Uzun bir dönem boyunca imgeler bu amaca hizmet ettiler. Farklı yüzeyler üzerine resmedilen imgeler; tanrısal 1şığı simgelerler. "Bu, imgenin tanrısal 1şığı simgeleyeceğine-ya da onu ikame edeceğine-yalnızca onun imgesine uygun gerçekleşmesi, diğer bir deyişle onu anıştırması anlamına gelir. Bu türden bir anıştırma ise benzeşmeye değil, benzeşmemeye dayanır" denilmektedir (Bayav, 2009, s. 105). Bir sanatçı olarak Bilgehan Uzuner sanatsal etkilenim süreciyle ilgili olarak; "Benim için nesnelere nasıl biçim verildiği değil, onun içinde gizli olanı bulup, onun sözüne de kulak vererek şekillendirmek önemlidir. $\mathrm{Bu}$ davranışa takunyayla çalışmaya başlamadan önce onunla hesaplaşmamı örnekleyebilirim. 2006 yılında takunyaları alıp bir süre inceledim. Bu formun içinde insan bedeni yattığını gördüğümde buluş gerçekleşmişti. Ardından birçok şey kolayca geldi” diye ifade etmektedir (Yüksel, 2011). 


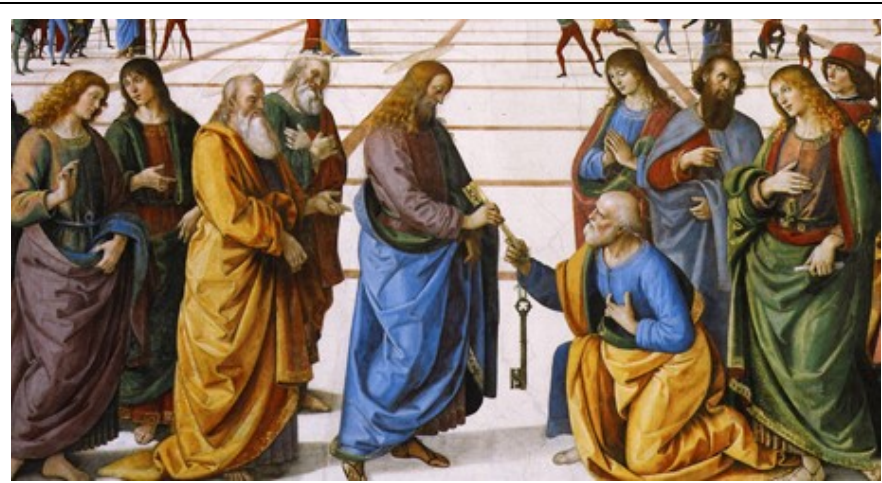

Görsel 10. Pietro Perugino, (1481), Krallı̆̆ın Anahtarlarının Aziz Peter'e teslim edilişi/Sistine Şapeli, Vatikan, Roma, İtalya

Sanatın dini yapılarda bir anlatı dili olarak kullanıldığı dönemlerde Hristiyanlık inancında dinsel öğretilerden dolayı önemli bir sembol olan anahtar formu resim ve heykel sanatında güçlü bir imge olarak işlenmiştir. İtalya'nın Rönesans dönemi ünlü ressamlarından Pietro Perugino' nun Papa Sixtus IV (1471-1484 döneminde) Roma'daki Sistine Şapelinde yer alan "İsa mesihin Krallı̆̆ın (cennetin) anahtarlarını aziz peter'e verme mesihleri” adlı fresk eserini bunun bir örneği olarak görebiliriz. Dinsel bir anlatıyı betimlemek için yapılmış olan bu eserde Anahtar konunun ana imgelerinden birini oluşturmaktadır. Resmin konusu gereği anahtar formu yorumlamacı bir üslupta ele alınmayıp realist bir üslupta işlenmiştir. Ayrıca resmin diğer özellikleri açısından da bakıldığında; Perugino'nun lineer perspektifini kullanması, iki boyutlu yüzeyin “düzlüğünü” azaltan ve üç boyutlu bir sahnenin inandırıcı bir görünümünü yansıttığı bu eseri erken Rönesans resminin en iyi örneklerinden biri olarak ta sanatta yerini almıştır (Görsel 10).
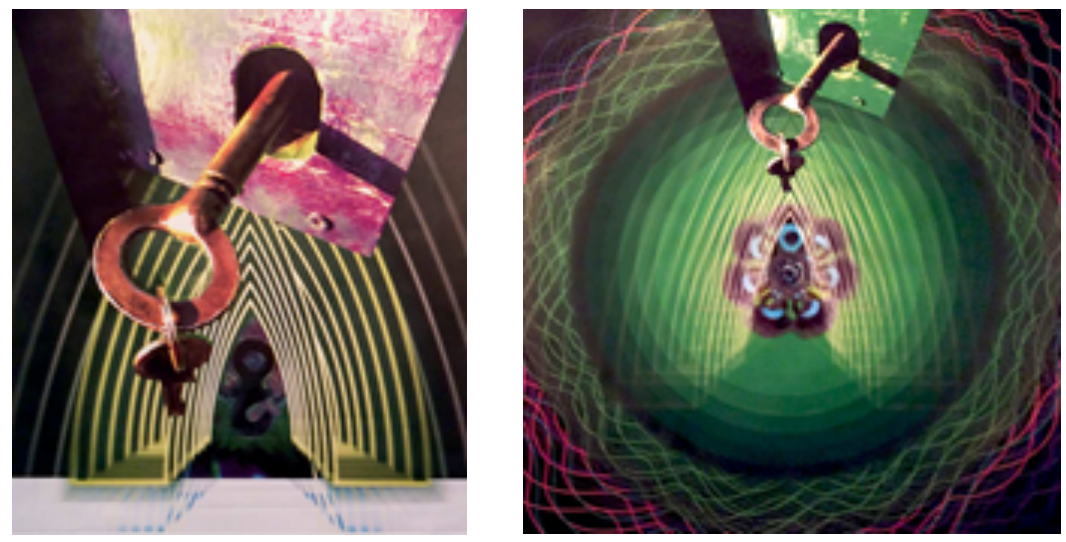

Görsel 11. Tülay Candemir, 2016, Kilit I, Kilit II, Digital Art

Sanatçı Candemir'in güncel bilgisayar teknolojileri ve araçlarıyla oluşturulmuş "Kilit I", "Kilit II", isimli çalışmaları ile ilgili yorumu; Proje Kapsamında oluşturulan “Telipinu'nun Kayboluşu” (Alparslan ve Alparslan, 2013, s. 418-419) adlı mitoloji örneğinden yola çıkarak, kullanılan simgeler ve semboller franktal bir düzlemde renklerin zıtlık etkisinden faydalanılarak yorumlama ve kurgulama süreci izlenmiştir. Hitit ritüellerindeki enerji frekanslarının franktal geometrik sembollerin tekrarlaryyla, kavramsal boyutta somutlaştırılması, izleyiciye bu enerji boyutunun yansıtılması amaçlanmıştır. Kilit 1 ve Kilit 2 eserinde 7 rakamından yola çıkarak 3 farklı imgenin enerjisel boyutunun simgeleştirme yoluna gidilmiştir (Görsel 11). "7 rakamının anatomik yapısından kapıları, kilidin formundan küpleri ve açılan kapıları iç içe paralel devam eden 
dairelerle simgeleştirildi. Hikâye Telipinu'nun öfkesini gazabını saldırganlığını ve sinirini franktal geometrik, tekrarlarla o anki enerji boyutu tanımlandı. Böylelikle izleyicinin çalışma ile etkileşim içerisinde olması gerçekleştirildi" (Candemir ve Topcuoğlu, 2016, s. 636).
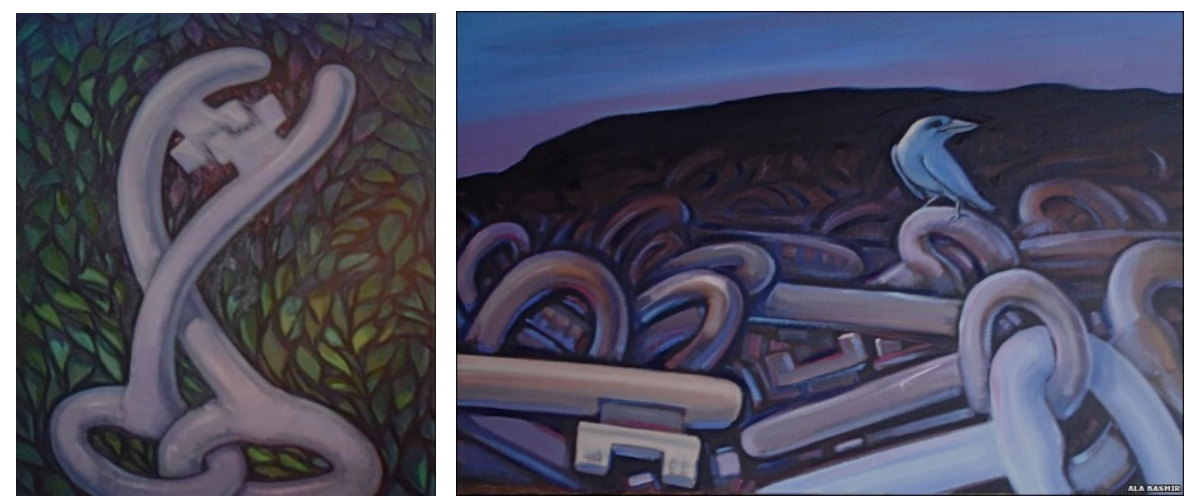

Görsel 12. Ala Bashir, 2010, İsimsiz, Fransa

Iraklı ressam Dr. Ala Bashir de resimlerinde anahtarı bir imge olarak ele almış ve bazen realist bazen de yorumlamacı bir üslupla anahtar formunu kullandığını görmekteyiz (Görsel 12). Uzun yıllar Saddam Hüseyin'in doktorluğunu da yürütmüş olan Bashir anahtarın kendisi için neyi sembolize ettiğiyle ilgili olarak: "Evin anlamı uzun yıllardır benim endişemdi ve Irak'tan ayrıldıktan sonra öne çıkan konu oldu. Ev için evrensel bir sembol ya da metafor arayışları, insan yaşamının biyolojik, sosyal, etnik, ekonomik, tarihsel ve psikolojik yönlerinin yanından geçiyordu. Anahtarın, tüm ihtilaflarıyla birlikte ev için sembol yerine bir mecaz olarak kullanılabildiğini gördüm" diye ifade etmiştir (Artlistings, 2010).

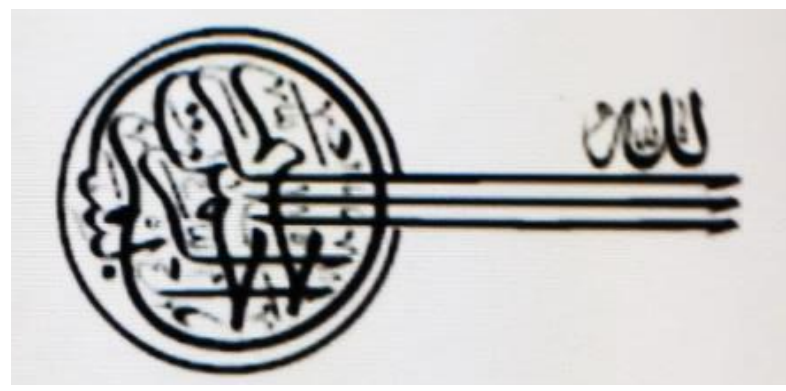

Görsel 13. Hat Sanatında Besmele III

İslam anlayışı içerisinde de anahtarın sembolik bir anlam taşıdığını görmekteyiz. Özellikle hat yazılarında rastladığımız anahtar biçimiyle ilgili olarak şunlar ifade edilmektedir;

Anahtar Motifli: "Bismillahirrahmanirrahim miftahi kullu kitabin/Besmele her kitabın anahtarıdır" Hadisi, Hâkim el Nişâburî'nin El-Mustedrak alâ el-Sahîheyn adlı hadis külliyatında yer almaktadır. Besmele motiflerinde sıklıkla rastlanan motiflerden biri de gerek bu hadisten gerekse anahtar nesnesinin özgürlügüü, başlangıcı simgelemesinden ötürü "anahtar" olmuştur. Metin işleme yazılımlarında Besmellah_2.ttf, Yazı Tipi Boyutu' nu 72 olarak atadığınızda yazdığınız 'e' harfi ise (Görsel 13)'deki şekle dönüşmektedir (Zariç, 2017, s. 198-199). 


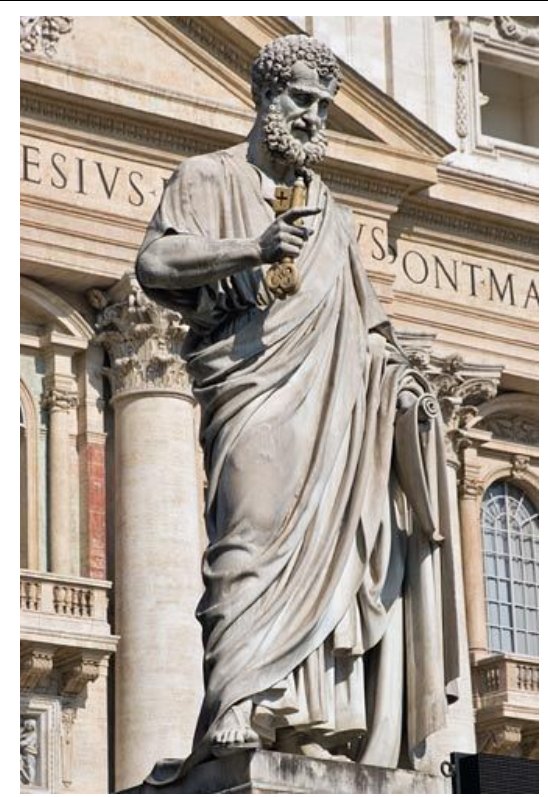

Görsel 14. Giuseppe De Fabris, (1840), Aziz Peter heykeli / Statue of Saint Peter, Aziz Petrus Meydani, Italya

Aziz Peter heykeli, on altıncı ve on yedinci yüzyılların dikkat çekici resimlerine ve heykellerine ikonografik olarak sadıktır; ilham ve duyguyu ifade eder, böylelikle sanatçının dönemin akademik titizliğine tepkisini gösterir. Sağ elinde, Philippi Sezarea'da Mesih'in kendisine vaat ettiği gücün sembolü; Sol elinde "Size cennetin krallığının anahtarlarını vereceğim" (Mt. 16-19) yazısını gösteren belge bulunmakta (Görsel 14). Elinde tuttuğu anahtarların biri gümüş kaplama, diğeri altın kaplamadır (St Peter's, t.y.). Anahtar formu burada realist bir üslupta işlenmiş ve anlatım nesnesi olarak kullanılmıştır.

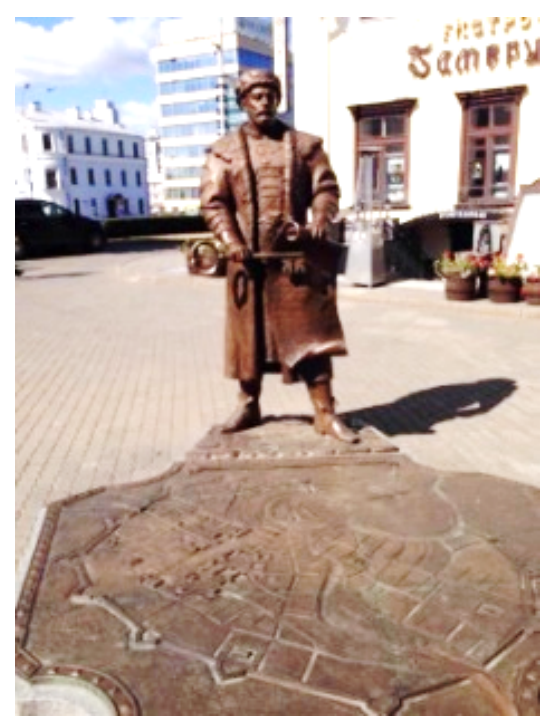

Görsel 15. Minsk şehri Belediye Başkanını tasvir eden bir heykel / A statue depicting the mayor of Minsk city, Rusya

Beyaz Rusya'nın Minsk şehrinde bulunan Belediye Başkanı heykelinin ellerinde de; Magdeburg kanununda Minsk şehrinin statüsünün kabulünü simgeleyen anahtar ve kraliyet tüzüğ̈̈ bulunmaktadır (Görsel 15). Bu anıtta yine anahtar imgesi gerçek işlevinin dışında bir sembol niteliği taşımakta olup kavramsal bir ifadede anlatım nesnesi olarak ele alınmıştır. Ülkemizde ve diğer ülkelerde de anahtar kent sembolü olarak görülüp 
kenti ziyarete gelen üst düzey bazı konuklara çoğunlukla belediye başkanları tarafindan kentin anahtarı sembolik olarak hediye edilmektedir.

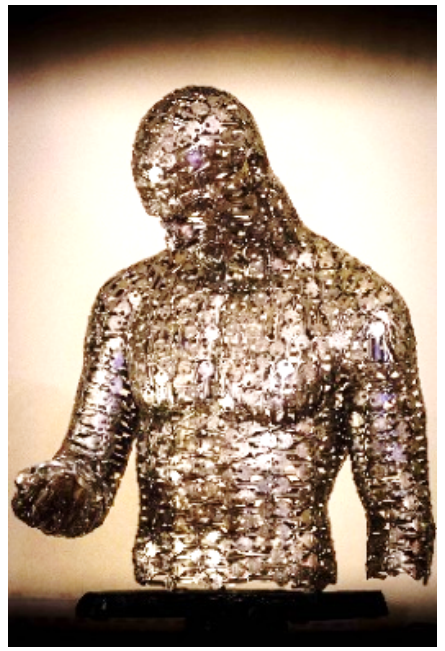

Görsel 16. Shaun Gag, 2016, Anahtar Adam 4 / Key Man 4, Ingiltere

İngiliz heykeltıraş Shaun Gagg tarafindan yapılan kaynaklı metal heykelde anahtarları insan figürlerini oluşturmak için kullanılmıştır (Görsel 16). Anahtarları birbirine kaynatarak heykelini oluşturmuştur. Anahtarlar görsel anlamda heykele hareket katmasının yanı sıra kavramsal olarak ta anahtarın insanda uyandırdı ğı hislerden dolayı sanat alımlayıcısıyla derinlemesine bağlar kurabileceği hissini vermektedir. Sanatçı elinde asma kilit tutan heykeliyle ilgili olarak; "Ona, nasıl anahtarsız açılacağını merak ediyormuş gibi bakıyor" diye ifade etmektedir (Gagg, t.y.).
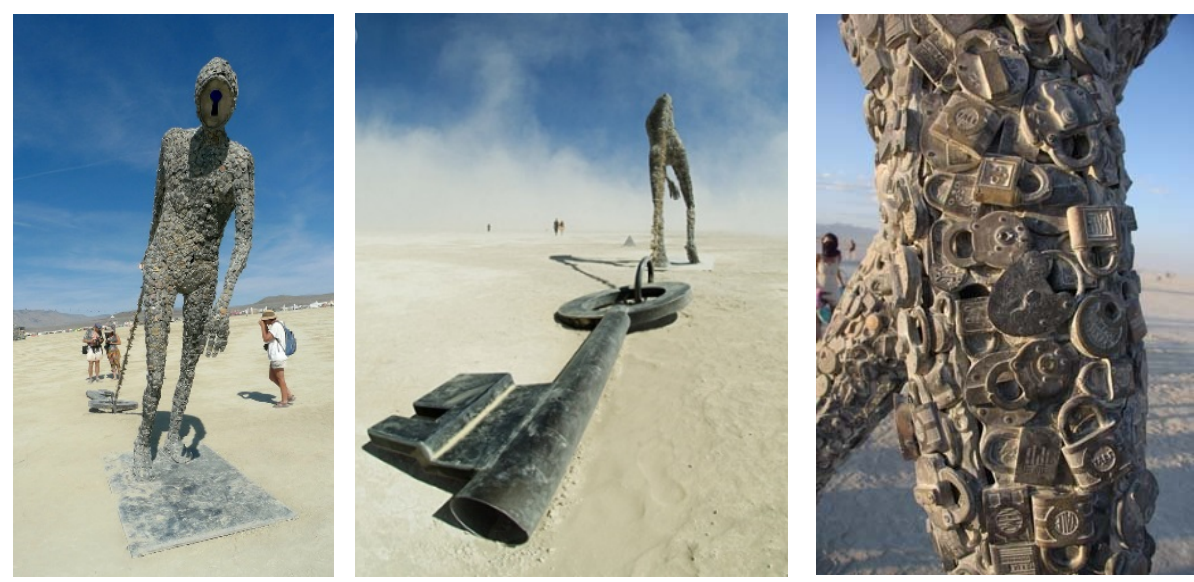

Görsel 17. Michael Christian, 2009, Kilitler ve Anahtarlar / Locks and Keys, ABD

“Kilitler ve Anahtarlar" isimli metal heykel ABD'li heykel sanatçısı Michael Christian tarafından ABD'nin Nevada eyaletinde Black Rock Çölü'nün ortasında her yıl geleneksel olarak tekrarlanan "Yanan Adam Festivalinde üretilmiştir. Heykel tamamen kapı kilitleri, asma kilitler, göğüs kilitleri, dolap kilitleri, araba kilitleri gibi kilitlerden oluşan figüratif bir çalışmadır (Görsel 17). Kilit adam binlerce küçük anahtardan oluşan zincirle çok büyük bir anahtarı sürüklüyor görünümündedir. Sanatçı eseriyle ilgili olarak; "Topladığımız tüm değerleri korumak için kilitleri kullanıyoruz" diye ifade etmektedir (Christian, 2018). ABD'li Yazar Ursula K. Le Guin eserle ilgili yorum olarak; "Hayal gücünün bastırılabileceğinden şüpheliyim. Eğer gerçekten bir çocukta onu tamamen ortadan kaldırırsanız, o bir patlıcan olarak büyüyecektir” demektedir (Le Guin, t.y). 


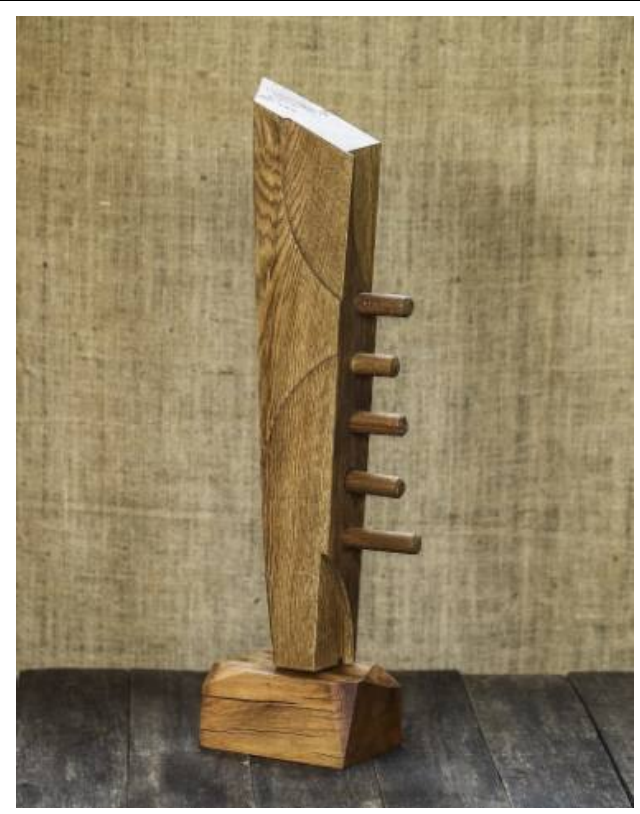

Görsel 18. Florin Constantinescu, 2016, Anahtar, Ahşap, Romanya

Romanya'nın Craiova kentinde yaşayan, imaj ve dijital grafikler mezunu, soyut dışavurumcu bir sanat anlayışına sahip sanatçı Florin Constantinescu anahtar çalışmasıyla ilgili olarak; "Anılar geçmişe değil geleceğe giden anahtardır" (Constantinescu, t.y.) diye ifade etmektedir (Görsel 18)
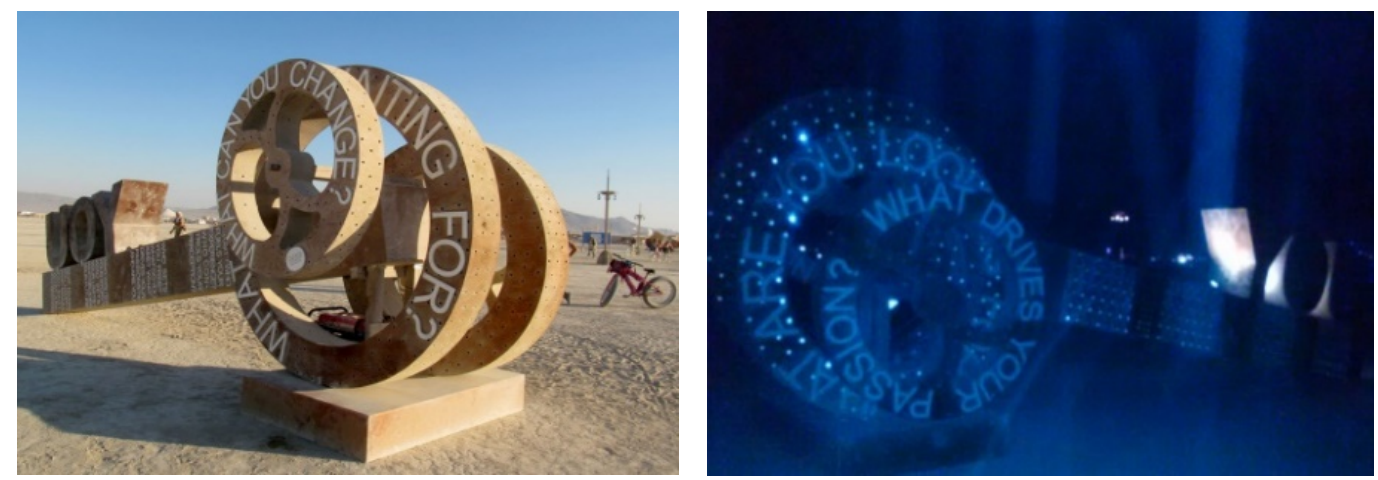

Görsel 19. Vassil Velkov, 2013, Anahtar siz siniz / You Are The Key, Interaktif sanat kurulumu, $A B D$

"Vassko Tasarım" Vassil Velkov ve ekibi tarafindan ABD'de Yanan Adam Festivali 2013 'te gerçekleştirilen "Anahtar siz siniz" isimli çalışma, yaklaşı 2000 harfin üzerinde soruları oluşturduğu plywood'dan yapılan etkileşimli bir sanat enstalasyonu (Görsel 19). Tasarımda imge olarak anahtar formu ele alınmış olup çalışmanın yüzeyinde " $\mathrm{Ne}$ arıyorsunuz?", "Ne bekliyorsunuz?", "Sizi ne engelliyor?" gibi sorular yazilıdır. Çalışmanın kavramsal yönüyle ilgili olarak sanatçı Velkov; "Tüm soruların cevabı olarak, kapıyı açan anahtarın parçası olan kolun üzerinde "SEN" yazmakta ve bu bize hayatımızdaki her şeyin nedeni ve cevabının kendimiz olduğunu hatırlatmaktadır" demektedir (Velkov, 2013). 

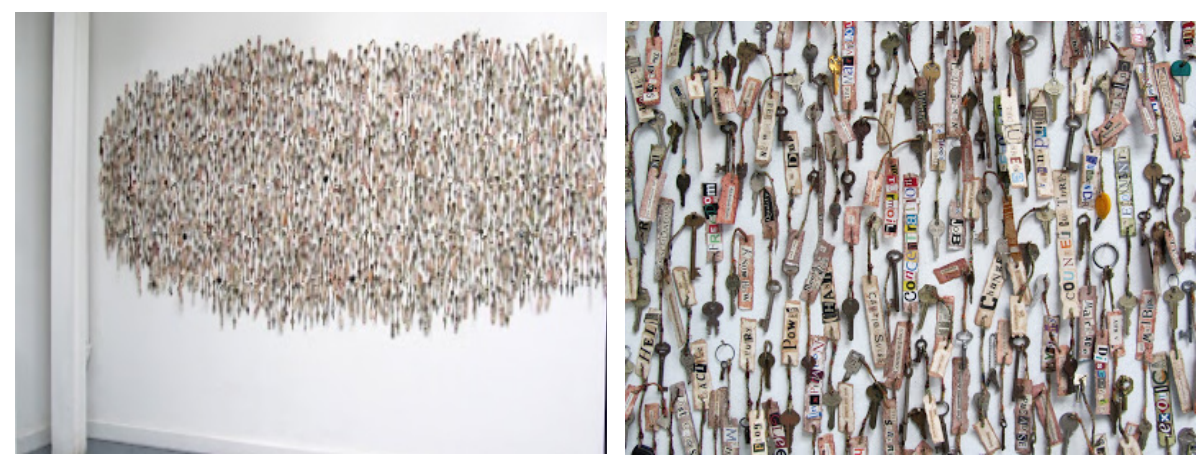

Görsel 20. Susan Lenz, 2011, Anahtarların Duvarl/The Wall of Keys

Kolombiyalı sanatçı Susan Lenz sanatsal kurulumlarında yeni ve etnografik anahtarları imge olarak kullanıp hazır nesneden sanatsal kurulumlar yapmaktadır. Yaklaşık 900 adet anahtar kullanarak gerçekleştirdiği "Anahtarların Duvarı" çalışmasıyla ilgili olarak; Her anahtarın, artık iplikler ve artık iplikler üzerine dikişler yapan zikzaklarla yapılmış bir kordonla bağlanmış el yapımı bir etiketi vardır (Görsel 20). Mutluluğun, bilgimin, kalbimin, saygımın, cehennemin, terfinin, doyumun, güvenli seyahatlerin, garajın, başarısızlığın, aşkın, bağlılı̆̆ın ve dünya barışının anahtarı. Şan, eğlence, hayvan manyetizması, dürüstlük, kıskançlık, dudakları ve bilgeliği için bir anahtar var demektedir (Art In Stitches, 2011).

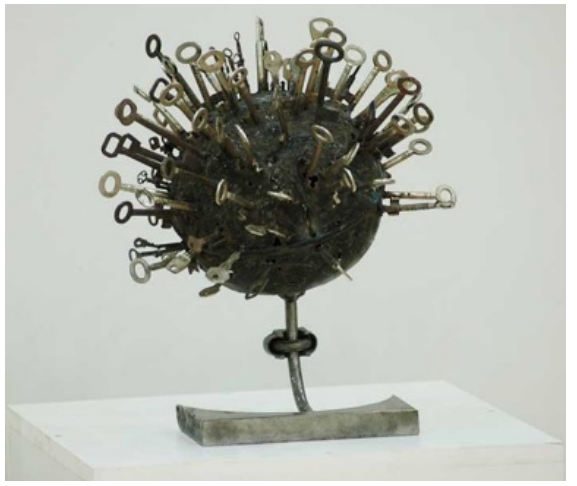

Görsel 21. Maksut Kesici, Paslı Anahtarlar, Metal Heykel

Sanatçı Maksut Kesici çalışmasını günlük hayatta kullandığımız farklı biçimlerdeki, boyutlardaki hazır anahtarları bir kürenin tüm etrafına kurgulayarak oluşturmuş ve alt kısımda bir asma köçek kullanmıştır. Asma köçek eserin üst kısmıyla ilgili gizemli bir his uyandırmaktadır. Yüzeyi kaplayan anahtarlar yaşadığımız dünyanın içerisinde gizemlerin bulunduğuna gönderme yapmış hissi uyandırmakta olup her gizemi de açacak bir anahtar varmış gibi durmaktadır (Görsel 21).
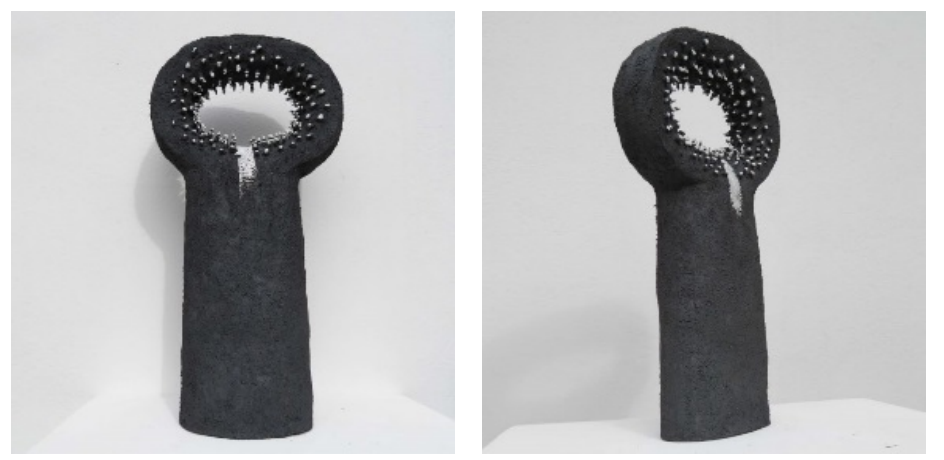

Görsel 22. Liliya Pobornikova, 2017, Anahtar / The Key, Bulgaristan 
Çağdaş Bulgar Heykeltıraş Liliya Pobornikova, porselen heykel çalışmasında imge olarak ele aldığ 1 anahtar formunu yorumlamacı bir üslupla çalışmıştır. Formun kavramsal yönünden çok formun kendisiyle ilgili plastik çözümlemeler içerisine girmiş ve yorumlamacı bir tavırla eserini oluşturmuştur. Eserde siyah ve beyazın renkleri kullanarak formun yüzeyinde oluşturduğu biçimleri vurgulamaya çalışmıştır (Görsel 22).
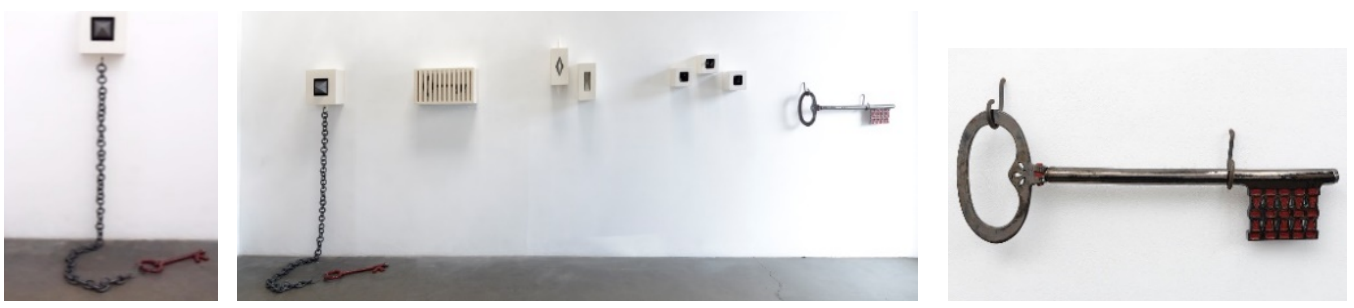

Görsel 23. Elizabeth Orleans, 2016, Dev Adımlar Kurulumu / Giant Steps Setup, sirlı seramikler, Bergamot İstasyonu çağdaş sanat mekânı sloan projelerinden, Kaliforniya, $A B D$

Philadelphialı seramik sanatçısı Elizabeth N. Orleans çalışmalarında etnografik anahtarı sanat imgesi olarak ele almıştır (Görsel 23). Elizabeth'in çalışmasıyla ilgili olarak; "sınırları aşan, hareketi, değişimi ve sonsuz zaman ihtimalini araştıran mimari müdahaleler oluşturarak önceden var olan alanları değiştirmeye olan ilgisini de artırıyor" denilmektedir (Orleans, t.y.).
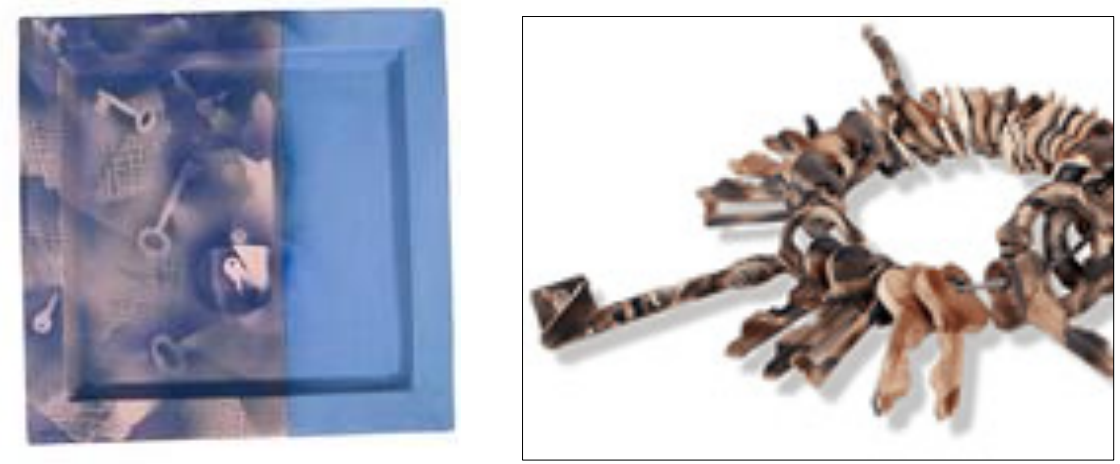

Görsel 24. Zehra Çobanl,, Seramik tabak, Seramik düzenleme, Türkiye

Sanatçı Zehra Çobanlı bu iki çalışmasında etnografik ve günümüz anahtarını imgelem olarak sır altı uygulamalarında, enstalasyon uygulamalarında kullanmıştır. Anahtarların gerçek biçimlerini deforme etmeden kullanmıştır. Anahtarlar sanatçının çalışmalarında bir anlatım nesnesi ve sembol olarak görünmektedir (Görsel 24).
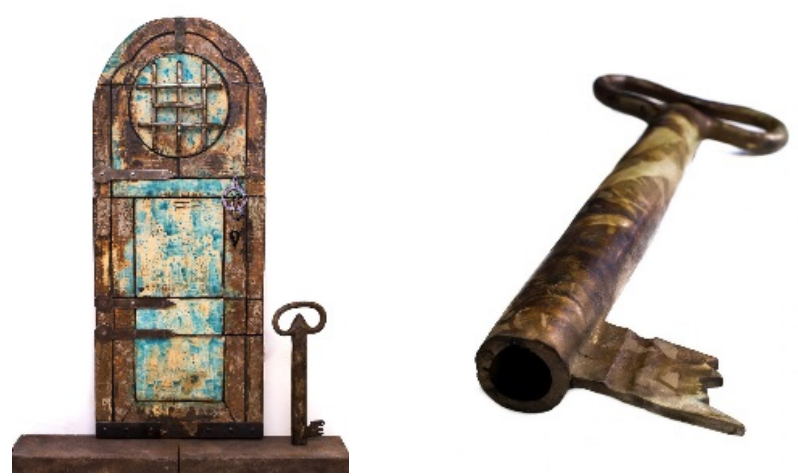

Görsel 25. Şenay Akkurt, 2016, Kapı, Anahtar, Seramik 
Seramik Sanatçısı Şenay Akkurt çalışmalarında; günlük yaşam içinde sıradanlaştırdığımız sorulara ve çok yakınımızda hatta kendi içimizde olduğunu fark edemediğimiz yanıtlarına gönderme yapıyor. Sanatçı imge olarak ele aldığı kilitlerle sanat alımlayıcısını yaşamdaki kilitler, kapalı kapılar ve çözüm arayışındaki seçilmiş anahtarlar arasında süregelen bir yolculuğa çıkarmayı hedeflemektedir (Görsel 25). Akkurt, "çalışmalarıyla, günlük yaşam içinde sıradanlaştırdığımız sorulara ve çok yakınımızda hatta kendi içimizde olduğunu fark edemediğimiz yanıtlarına gönderme yapıyor” denilmektedir (Seramik sergisi, 2016).

\section{Sonuç}

Bir araştırmacı, etnograf, sentezci, analizci olabilen sanatçı imgelemlenmeleri sonucunda oluşturduğu eserleriyle; toplumlara dün, bugün ve yarın arasında bir köprü görevi görür. Sanatçının eserini oluşturmada; yaşadığı çevre, eğitimi, var olduğu çağın özellikleri, gezip görebildikleri, duydukları, hisleri, psikolojik durumu ve benzeri etmenler önemli faktörlerdir. Sanat eserleri sanatçıların ussal ve duygusal birikintilerinin ürünüdür diyebiliriz. Ussal, duygusal birikintiler ve imgelenmelerle evrensel bir özelliğe sahip olan sanat dilinin anlatım gücünü kullanarak yeni imgeler, anlatılar, öğretiler ortaya korlar. Soyut veya somut diye ifade ettiğimiz her şey sanatçı için her an sanatsal etkilenim argümanına dönüşebilir. İcat edildiği süreç arkeolojik dönemlere kadar uzanan anahtarda koruma, saklama amaçlı işlevselliğinin insana verdiği güven duygusunun yanı sıra açma fiilinin şifresi gibi olması niteliğiyle de hem bireyler için hem de toplumlar için önemli bir araç gereç olmuştur.

Anahtar formunu içerisinde barındıran sanatsal yapıtların araştırılıp irdelendiği bu çalışma ışığında; anahtarın form yapısı, anlamsal değerleriyle sanatta ve sanatsal pratikleri ortaya koymada önemli bir nesne olarak işlendiğini söyleyebiliriz. Anahtarlar genel yapısıyla her kültürde rastlayabildiğimiz nesneler olsa da üzerlerine işlenmiş özel yapılarıyla kültürden kültüre farkl11ıklar göstermektedir. $\mathrm{Bu}$ farkl11ıklarıyla da var oldukları toplumların maddi, manevi kültürel birikimlerini üzerlerinde veya genel biçimlerinde taşımalarıyla da toplumların birer kültür imgeleri ve temsilcileridirler. Özellikle arkaik, etnografik nitelikteki kapı anahtarları naif, estetik duruşlarıyla, üzerlerinde taşıdıkları biçimlerle, sembolik şekillerle, genel formlarıyla ve üzerlerine yüklenmiş olan anlamlarla geçmişten günümüz çağdaş sanat anlayışına kadar gelen süreçte tüm dünyada sanatçıların eserlerini ortaya koymada önemli bir etkilenim nesnesi olmuştur. Yaşam kültürü içerisinde yer alan bu tür işlevsel araç gereçlerin işlevselliklerinin ötesinde sanatta güçlü bir imgelem konusu olabileceği ve imgeye dönüşebileceğine de örnek oluşturmaktadır diyebiliriz.

\section{Kaynakça}

Akbulut, U. (2014, 7 Nisan). Kapı kilidi 4000 yıl önce ortaya çıktı. Erişim Adresi: http://www.uralakbulut.com.tr/wp-content/uploads/2014/04/KAPI-KİLİİ-4000YIL-ÖNCE-ORTAYA-ÇIKTI-7-NISAN-2014.pdf

Albayrak, A. (2015). Sanat yapıtlarının nasıl anlamlandırıldığı ve izleyiciyle iletişimine dair bir inceleme. Erciyes Sanat, Erciyes Üniversitesi Güzel Sanatlar Enstitüsü Dergisi, 4, 11-22. Erişim adresi: https://docplayer.biz.tr/19799068-Editorler-vekurullar.html

Allef, P. (2013, 1 Aral1k). The Phaistos Disk: A New Approach. Popular Archaeology [Blog Yazıs1]. Erişim adresi: http://www. phaistosgame.com/PopularArchaeology Article5.htm 
Alparslan, D. M. ve Alparslan, M. (2013). Hititler: bir Anadolu imparatorluğu. İstanbul: Yapı Kredi Yayınları.

Anahtar. (t.y.). Türk Dil Kurumu Sözlüğ̈̈ içinde. Erişim adresi: http://www.tdk.gov.tr/index.php?option=com_gts\&arama=gts\&guid=TDK.GTS.5c 8932d64c8fc3.68348229

Arnheim, R. (2007). Görsel Düşünme (R. Öğdül, Çev.). İstanbul: Metis Yayınları.

Art In Stitches. (2011, 23 Nisan). The Wall of Keys [Blog Yazıs1]. Erişim adresi: http://artbysusanlenz.blogspot.com/ 2011/04/wall-of-keys.html

Artlistings. (2010, 3 Mart). Saddam Hussein's personal physician to show works at University of Leicester [Haber Yazıs1]. Erişim adresi: https://www.artlistings.com/ Magazine/Saddam-Hussein-s-Personal-Physician-to-Show-Works-at-Universityof-Leicester-68443

Atalayer, F. (2005). Toprak-seramik: imge, imgelem, imlem ve yaratic1lık. Anadolu Sanat, Anadolu Üniversitesi Yayınlarl, 16. Erişim adresi: http://hdl.handle.net/11421/957

Bayav, D. (2009). Resim sanatında ve sanat eğitiminde imge. Trakya Üniversitesi Sosyal Bilimler Dergisi, 11 (2), 105-122.

Berger, J. (1995). Görme biçimleri (Y. Salman, Çev.). İstanbul: Metis Yayınları.

Candemir, T. ve Topcuoğlu, I. (2016). Bir proje, bir sergi; Hitit ritüelleri. Uluslararası Sosyal Araştırmalar Dergisi, 9 (44), 632-646.

Christian, M. (2018, 3 Nisan). Locks \& keys [Blog yazısı]. Erişim adresi: http://michalchristian.com/portfolio/key-note/?portfolioID $=8$

Constantinescu, F. (t.y). Key sculpture by Florin Constantinescu [Blog yazıs1]. Erişim adresi: https://www.saatchiart.com/art/Sculpture-Key/670208/2490302/view

Fikriyat. (2017, 12 Ağustos). Kilit ustası Yuğuran'dan medeniyetlerin kilidi [Blog yazısı]. Erişim adresi: https:// www.fikriyat.com/geleneksel-sanatlar/2017/08/12/kilitustasi-yugurandan-medeniyetlerin-kilidi

Frangipane, M. (2004). Arslantepe. Alle origini del potere Arslantepe la collina dei leoni. İtaly: Electa.

Gagg, S. (t.y). Shaun Gagg key man 4 [Blog yazısı]. Erişim adresi: https://shaungagg. co.uk/shaun-gagg-lock-and-key-man-2-sold/

Hançerlioğlu, O. (2008). Felsefe sözlüğü (16.Basım). İstanbul: Remzi Kitabevi.

İmge. (t.y.). Türk Dil Kurumu Sözlüğ̈̈ içinde. Erişim adresi: http://www.tdk.gov.tr/index.php?option=com_gts\&arama=gts\&guid=TDK.GTS.5c 89331adff474.49974537

İşçen, A. (2008, 23 Ağustos). Kapadokya'da kilitler ve anahtarlar [Blog yazıs1]. Erişim adresi: http://www.cappadociaexplorer.com/detay.php?id=103\&cid=47

İşçen, A. (2015, 7 Ağustos). Kilitle anahtarın sonsuza uzanan dostluğu [Blog Yazıs1]. Erişim adresi: https:// www.ismek.ist/blog/icerik. aspx?p=1214 
Le Guin, U. (t.y). Key note by Michael Christian [Blog yazısı]. Erişim adresi: http://www.dusttoashes.com/all-burning-man-photos/key-note-perspective/

Orleans, E. (t.y.). Giant Steps Installation [Blog yazısı]. Erişim adresi: http://www.elizabethorleans.com/installations/nggallery/installations/giant-steps

San, İ. (2003). Sanat eğitimi kuramları. Ankara: Ütopya Yayınları.

Saraçoğlu Çelik, S. (2015). Lost treasures: locks. International Journal of Science Culture and Sport, 3 (1), 96-112. doi: 10.14486/IJSCS230

Saraçoğlu, S. ve Karakaş, B. (2007-2008). Anadolu kültüründe kilit (Doğu ve Güneydoğu Anadolu örnekleri). Osmanlı Bilimi Araştırmaları, 9 (1-2), 137-150. Erişim adresi: http://dergipark.gov.tr/download/article-file/13233

Schlage's History of Locks. (t.y.). An introduction to the history of locks [Blog Yazis1]. Erişim adresi: http://www.accuratesecuritypros.com/articles/ historyoflock.htm

Seramik sergisi Şenay Akkurt. (2016, 3 Şubat). Aç kapıyı sen geldin [Blog yazısı]. Erişim adresi: http://www.kitaptansanattan.com/etkinlikler/seramik-sergisi-senay-akkurtac-kapiyi-sen-geldin/

St Peter's Basilica. (t.y.). Statue of St Peter by Giuseppe De Fabris, 1840 [Blog Yazıs1]. Erişim adresi: http://stpetersbasilica.info/Exterior/StPeterStatue/StPeterStatue.htm

Şahin, H. (2018, 3 Kasım). Binlerce yıl önce Arslantepe'de kullanıldı. Malatya Haber. Erişim adresi: http://malatyahaber.com/haber/binlerce-yil-once-arslantepedekullanildi/

Ünal, İ. (1963). Kale anahtarları. Ankara Üniversitesi Illahiyat Fakültesi Dergisi, 11 (1), 119-152. doi: 10.1501/Ilhfak_0000000351

Velkov, V. (2013, 4 Nisan). You are the key art installation [Portfolio]. Erişim adresi: http://www.raliart.com/portfolio_page/you-are-the-key-art-installation/

Yüksel, H. (2011, 27 Ağustos). Prof. Bilgehan Uzuner ile söyleşi [Blog Yazıs1]. Erişim adresi: http://www. mimdap.org/?p=69068

Zariç, M. (2017). Hat sanatında Besmele III-bağlam, motif, geometrik form. Batman Üniversitesi Yaşam Bilimleri Dergisi, 7 (2/1), 192-224. Erişim adresi: http://dergipark.gov.tr/download/article-file/391457

\section{Görsel Kaynakçası}

Görsel 1. Asur kilidi ve çizimi/Assyrian lock and drawing (t.y.). [Fotoğraf, Çizim]. Traditıons: Locksmıths. Blacksmith Organization of Arkansas. voice, 18. Erişim adresi: http://blacksmithsofarkansas.org/wp-content/uploads/2016/05/BOA-Voice2016-04-High-Res.pdf

Görsel 2. Ahşap Kilit Sistemi rekonstriksiyon çizim/Wood Lock System Reconstriction Drawing [Çizim]. Kaynak: Frangipane, M. (2004). Arslantepe, Alle origini del potere Arslantepe la collina dei leoni, İtaly: Electa, 85.

Görsel 3. Ahşap kilit ve anahtar [Ahşap]. Malatya Etnografya Müzesi

Görsel 4. Osmanlı dönemi ahşap kale anahtarları [Ahşap]. Kaynak: Ünal, İ. (1963). Kale anahtarları. Ankara Üniversitesi İlahiyat Fakültesi Dergisi, 11 (1), 142-144. Erişim adresi: http://dergiler.ankara.edu.tr/dergiler/37/737/9412.pdf 
Görsel 5. Antik Roma bronz yüzük anahtar/Ancient Roman Bronze Ring Key [Metal]. Erişim adresi: http://www. ancientresource.com/lots/roman/romankeys _locks.html

Görsel 6. Osmanlı dönemi gümüş anahtarları [Metal]. Kaynak: Ünal, İ. (1963). Kale anahtarları. Ankara Üniversitesi Ilahiyat Fakültesi Dergisi, 11 (1), 136. Erişim adresi: http://dergiler.ankara.edu.tr/dergiler/37/737/9412.pdf

Görsel 7. Silistre Kalesi’nin gümüş anahtarı [Gümüş]. Kaynak: Genç, U. ve Bilirgen, E. (2015). Topkap1 Sarayı Hazinesindeki Kale Anahtarlar1, 213. Erişim adresi: https://www.academia.edu/2225664/Topkap\%C4\%B1_Saray\%C4\%B1_Hazinesin deki Kale_Anahtarlar \%C4\%B1

Görsel 8. Yanık, G. (t.y). Kapı kilitleri ve anahtarları [Metal]. Erişim adresi: http://ismek.ist/ blog/icerik.aspx?p=6908

Görsel 9. Kapı anahtarları [Metal]. Mehmet Yuğuran koleksiyonu. Erişim adresi: https://www.ismek.ist /blog/icerik. aspx?p=1214

Görsel 10. Perugino, P. (Sanatçı). (1481). Krallığın anahtarlarının Aziz Peter'e teslim edilişi/Perugino's Christ Handing the Keys to Saint Peter [Resim]. Erişim adresi: http://www.italianrenaissance.org/perugino-christ-handing-keys-peter/

Görsel 11. Candemir, T. (Sanatçı). (2016). Kilit I, kilit II [Digital Art]. Kaynak: Candemir, T. ve Topcuoğlu, I. (2016). Bir proje, bir sergi; Hitit ritüelleri. Uluslararası Sosyal Araştırmalar Dergisi, 9 (44), 636.

Görsel 12. Bashir, A. (Sanatçı). (2010). [Yağlı Boya]. Erişim adresi: https://www. artlistings.com/Magazine/Saddam-Hussein-s-Personal-Physician-to-Show-Worksat University-of-Leicester-68443

Görsel 13. Hat Sanatında Besmele III [Hat]. Kaynak: Zariç, M. Hat sanatında Besmele III-bağlam, motif, geometrik form. Batman Üniversitesi Yaşam Bilimleri Dergisi, 7 (2-1), 199.

Görsel 14. De Fabris, G. (Sanatçı). (1840). Aziz Peter heykeli/Statue of Saint Peter [Heykel]. Erişim adresi: http://lonelypilgrim.com/ 2012/05/14/the-tomb-of-st-peter/

Görsel 15. Minsk şehri Belediye Başkanını tasvir eden bir heykel/A statue depicting the mayor of Minsk city [Heykel]. Erişim adresi: https://www.tripadvisor.com.tr/Attraction_Review-g294448-d7296433-ReviewsMinsk_City_HallMinsk.html\#photos;aggregationId=101\&albumid $=101 \&$ filter $=7 \&$ $\mathrm{ff}=228017778$

Görsel 16. Gagg, S. (Sanaţ̧1). (t.y.). Anahtar Adam 4/Key Man 4 [Heykel]. Erişim adresi: https:// shaungagg.co.uk/shaun-gagg-lock-and-key-man-2-sold/

Görsel 17. Christian, M. (2009). Kilitler ve anahtarlar/Locks and Keys [Metal Heykel]. Erişim adresi: http://michaelchristian.com/portfolio/key-note/?portfolioID=8

Görsel 18. Constantinescu, F. (Sanatçı). (2016). Anahtar/Key [Ahşap Heykel]. Erişim adresi: https://www. saatchiart.com/art/ Sculpture-Key/670208/2490302/view

Görsel 19. Velkov, V. (Sanatçı). (2013). Anahtar siz siniz/You Are The Key [İnteraktif sanat kurulumu]. Erişim adresi: http://www.raliart.com/portfolio_ page/you-arethe-key-art-installation/ 
Görsel 20. Lenz, S. (Sanatçı). (2011). Anahtarların duvarı/The Wall of Keys [Karışık malzeme düzenleme]. Erişim adresi: http://artbysusanlenz.blogspot.com/2011/04/wall-of-keys.html

Görsel 21. Kesici, M. (Sanatçı). (t.y). Paslı anahtarlar [Metal Heykel]. Erişim adresi: http://turkishpaintings.com/index.php?p=34\&l=1\&modPainters_artistDetailID=27 11

Görsel 22. Pobornikova, L. (Sanatç1). (2017). Anahtar/The Key [Porselen Heykel]. Erişim adresi: $\quad$ http://www.artparks.co.uk/artpark_sculpture.php?sculpture=10240\& sculptor=liliya_pobornikova

Görsel 23. Orleans, E. (Sanatçı). (2016). Dev adımlar kurulumu/Giant Steps Setup [Seramik Düzenleme]. Erişim adresi: http://www.elizabethorleans.com/installations/nggallery/installations/giant-steps

Görsel 24. Çobanlı, Z. (Sanatçı). (t.y). Seramik tabak, Seramik düzenleme [Seramik]. Erişim adresi: http://www. zehracobanli.com/zehra-cobanli-mavi-blue-eserlerworks.html

Görsel 25. Akkurt, Ş. (Sanatçı). (2016). Aç Kapıyı Sen Geldin [Seramik]. Erişim adresi: https://www.istanbul.net.tr/etkinlik/foto-galeri/senay-akkurt-ac-kapiyi-sen-geldin/ $63510 / 15$ 